\section{Grappling with dirty past}

\section{Munich}

ThE East German environmental movement took its first shaky steps toward political responsibility last week with the formation of the 'Green Party of the German Democratic Republic'. In its first statement, the party criticized materialism and advocated reducing environmental pollution.

But the party, founded over the objections of other ecologically minded people in East Germany, will have to develop a more solid programme in the next few months if it is to achieve even a fraction of its goal of ecological reform in a socialist framework. Nevertheless, the founding of the party was considered significant enough to be reported widely in the East German media and to attract support from the West German Green Party.

Co-founder Gerhard Bächer admits that winning support will be difficult in a country where everyone pays lip service to ecology. Even members of the ruling Communist Party have called for an "ecological reconstruction" of the country. Bächer says that the Greens have received anonymous phone calls from Communist Party members, insinuating that they have shown right-wing tendencies.

A bigger threat is the fragmentation of green thought between the new party and other left-wing groups such as New Forum. Bächer claims that the difficulties have been dealt with, but a West German Green who visited last week said that many disagreements remain. Members of the opposition movement New Forum also fear that they could be split by difficult choices between preserving the environment in East Germany or opting for profitable but polluting activities that bring in hard currency. The environmental side had been gaining ground in East Berlin earlier this year, but the collapse of the government and the need to earn Western money may turn the tide.

If it can arrive at a common platform, the Green Party will have a lot to do in East Germany, which has always relied for energy on soft bituminous coal. Huge strip-mining machines have churned up the countryside, and when the coal is burned, sulphur compounds are released directly into the atmosphere. Smog is a permanent problem in all East German cities, made worse by the black, foulsmelling exhaust from the two-stroke engines of Trabants, the least expensive East German cars.

The East German Greens are probably the only Green Party in the world that favours nuclear energy, but they support it only for want of alternatives. But their support does not extend beyond completing the nuclear power plant at Stendahl that is under construction. They are against new plants, but can suggest no likely alternatives that East Germany can afford.

Although East Germany has never had a significant nuclear accident, the uranium mines in the south of the country have been a continual health threat for East Germans who live nearby. The East German government has begun to publish radiation and air pollution figures for the first time in its history.

The East German Greens will be preoccupied with such basic issues for a long time before they need to consider genetic engineering and other technologies that

IN VITRO FERTILISATION

\section{Reformation of advisory board urged}

\section{Washington}

THE US Congress can now be added to the list of agencies trying to prod the US federal government into reconstituting the Ethics Advisory Board (EAB), the committee with responsibility for overseeing research on in vitro fertilization (IVF). In a report issued this week, the House of Representatives committee on government operations urges the government to abide by the regulations of the Department of Health and Human services which require it to set up the board. It is an "embarrassment" to the department and to the Public Health Service that the last five secretaries for health have ignored these regulations, says the committee.

It also urges the present Secretary for Health, Louis Sullivan, to implement the board's recommendation, made in 1979 before its charter was allowed to expire, to exempt research on embryos less than 14 days old from the need to be reviewed by the EAB. Other restrictions would be adequate, such as requiring the informed consent of the couple from whom the embryo was generated or restricting the number of eggs that can be fertilized.

Reinforcing the comments made by the Institute of Medicine in a report issued in November (see Nature 342, 218; 1989), the committee complains of the inadequacy of current IVF research and the poor infertility services available.

In line with the controversy surrounding this issue, five of the 15 Republican members of the committee signed a dissenting statement which says that there is no evidence that significant increases in federal funding for this research will improve its quality. It also says that there are fears that an increase in funds for infertility research could strip funds from AIDS research, and that, because the private sector is involved in this research, this is "not the best use of scarce tax dollars".

Christine McGourty exercise the West German Greens.

What may be the biggest challenge for the Greens in East Germany has little to do with ecology. Bächer warned against a "disturbing" tendency to favour reunification with West Germany as a way to help East Germany out of economic decay, saying that the West German style of economic success has its consequences, not least for the environment. "People's eyes popped out" on their trips to the West during the first weeks after the opening of the wall, said Bächer, but he and his party hope to convince them that they should consider the price before buying the goods.

Steven Dickman

\section{COLD FUSION}

\section{An old-fashioned love-song}

\section{Tokyo}

Cold fusion reared its head again last week in Japan with two independent research groups claiming to have detected strong neutron bursts from electrochemical experiments. The news was splashed across the front pages of newspapers, reported on national television and picked up by the US Wall Street Journal. But Japanese experts on neutron monitoring are sceptical.

Kunihide Nishizawa and Nobuhiko Wada of Nagoya University say they detected neutron emissions 20,000 times background levels from palladium electrodes that had been soaked in deuterium gas then subjected to a high voltage. Close on the heels of this announcement, a group at Osaka University, headed by Yoshiaki Arata, claimed to have detected neutron emissions 25,000 to 2.5 million times background levels when a voltage was applied to thick palladium rods immersed in heavy water.

But, according to one Japanese expert, the detector used by both groups, called a BF3 counter, is intrinsically very sensitive to vibration, and sometimes shows pulselike signals unrelated to neutron emission. Wada and Nishizawa should present pulse-height data before they claim neutron detection, he says.

The Osaka University results are more highly regarded, because multiple detectors were used and pulse-height data were presented. But neither group has examined the energy spectra of the neutrons and thus cannot claim that fusion is the cause, experts say. As one researcher from Japan's new National Institute for Fusion Science put it "we want evidence that the signals arise from neutrons due to nuclear fusion processes" but "some Japanese scientists still sing an oldfashioned love song composed by Pons and Fleischmann". David Swinbanks 